\title{
ENVIRONMENTAL AND SOCIAL RESPONSIBILITY REPORTING. DO MACEDONIAN COMPANIES DISCLOSE THOSE INFORMATION AND HOW?
}

\author{
Jadranka MRSIK 1 \\ Ninko KOSTOVSKI ${ }^{2}$
}

DOI: 10.1515/tjeb-2015-0016

Incorporating environmental impact into financial reports is becoming standard practice in the $21^{\text {st }}$ Century. Investors are aware of the need for environmentally correct operations since failures in this domain lower the price of shares. However, in terms of regulation, in most of the countries, environmental reporting remains voluntary. Institutions dealing with development and promotion of the modern accounting and financial reporting standards encourage companies to concurrently report for their environmental activities. The only question is how. Accounting may include information on the environmental impact only if it is quantitative and monetary. Since many nuances of the issues remain difficult to quantify, corporations opt to separately report on their environmental practices. The aim of this paper is to examine the accounting and stock market regulations and the practice of reporting for environmental impact of the operations of the leading Macedonian companies. We selected ten companies that make the Macedonian Stock Exchange Index and additional five companies with significant environmental impact. We reviewed their annual reports and interviewed their financial officers. The results show that the environmental and social responsibility reporting is left to the companies and their management and its perception of the need for keeping posted the major stakeholders and the most appropriate way to do it. As a consequence, many large Macedonian companies do not refer to these issues in their annual addressing to the stakeholders. The findings of this paper can motivate the regulatory body and the government to require more transparency and disclosure of the sustainability information.

Keywords: environmental accounting, social responsibility reporting, good governance, business accountability.

\section{JEL Classification: M41, M48, 016.}

\footnotetext{
${ }^{1}$ Associate Professor, University American College Skopje, Republic of Macedonia.

${ }^{2}$ Associate Professor, University American College Skopje, Republic of Macedonia.
} 


\section{Introduction}

All companies prepare reports on their financial results for the needs of shareholders, creditors, investors, governments, but few of them include information of their social and environmental activities therewith in, or in a form of separate reports. A common traditional belief is that businesses need only report on activities that can be measured and are required under the laws, accounting standards or stack-exchange listing rules. An environmental report is the production of narrative and numerical information on an organization's environmental impact within the reporting period (ACCA, 2015).From that point of view to prepare, a non-financial report can be complicated because of difficulties in measuring the environmental impact. On the other hand, people no longer think that businesses should be allowed to take from society without also accounting back to society (and not just to shareholders) on how they behave with regard to the environmental impact of their operations (ACCA, 2015). Businesses have become aware of the environmental implications of their operations because they are exposed to the investors' perception of their risks and consequences when the risks will arise. Investors are increasingly interested in the analysis of the environmental risks when they select securities for their portfolios. Proper environmental risk management and environmentally sensitive corporate governance are becoming critical for many companies, since the outcomes of environmental accidents or related lawsuits may be detrimental for the business and for the price of its shares. Consequently, there is a rising interest by the wider community of users of the financial reports to integrate these issues into the annual reports and in the mandatory disclosures of investors' sensitive information. To achieve this, the entire accounting system, especially its managerial segment, have to be adequately prepared to capture, record and report the environmental protection data and information in a methodologically correct and, as much as it is possible, in a standardized way. In other words, this subset of accounting should also conform to the centuries-old accounting principles of objectivity, reliability, comparability and so on and so forth, as Bebbington and Cray (2001) have noted.

The integrated reporting is not yet compulsory for the companies in many countries, including the emerging ones. The big international companies whose business and activities are visible and sensitive to the general opinion are pioneers in disclosing information about their social and environmental activities, mostly because of the public pressure. According to the Hauser Institute for civil society (2015) CSR reporting has increasingly become a field of interest as social pressure for greater regulation and transparency of corporations and financial markets continues to mount. The evidence of an increased number of companies reporting on their CSR initiatives is their growing percentage from 64 to 71, between 2011 and 2013 worldwide (KPMG, 2013). According to the GRI (2015) 93\% of the world's largest 250 corporations are reporting on their sustainability performance.

DE GRUYTER OPEN 
A number of institutions and organizations advocate the benefits of offering this information to both internal and external stakeholders. The GRI convinces us that an effective sustainability reporting cycle, which includes a regular program of data collection, communication, and responses, should benefit all reporting organizations, both internally and externally. The result from the PricewaterhouseCoopers experiment suggests to the companies that greater access to more contextual and non-financial information increases the confidence of securities analysts when preparing recommendations for the buying/selling of companies' shares. The KPMG (2013) view on corporate responsibility is that many companies no longer see it as a moral issue, but a core business risk leading to the question of what potential financial impact of those risks is and what the company is doing to mitigate it.

The stock markets' regulatory bodies and stock exchanges in developed countries are interested in prescribing the non-financial disclosure requirements for publicly traded companies. According to the Hauser Institute (2015) there are considerable differences between developed and developing countries in these terms. The government in some countries (Finland, China, and Spain) prescribes CSR obligations for non-listed state-owned companies. In other countries (Australia, Canada, UK, Sweden), CSR regulations exist for issuers of financial products and for pension plan administrators to disclose about the selection, retention or realization of an investment. Some of the countries (USA, Canada, UK, Singapore) with developed stock markets have even established stock exchanges for social enterprises and some of them (Germany) have introduced a multi-tier system of listing according to the level of the companies' best practices.

On the other hand the requirements for disclosing on-financial information in developing countries are mainly for general CSR activities and not specifically for environmental activities.

The listed companies on the Macedonian Stock Exchange (MSE) have an obligation to regularly disclose consolidated and unconsolidated audited financial statements (Audit opinion, Balance Sheet, Income Statement, Cash Flow Statement, Statement of changes in equity and Notes to Financial Statements) and Annual report of operation within 7 days of the acceptance by the Shareholder Assembly (MSE, n.d.). Along with financial data, the companies are obliged to disclose their non-financial data and information, but not the environmental reporting. Only the Macedonian joint stock companies admitted to super listing must file annual reports of their compliance with the corporate governance code of the Macedonian Stock Exchange from 2006 on "comply or explain" basis. We have reviewed the Code and we did not find the provisions for environmental reporting included. The companies' compliance with the Code is still not mandatory but they are obliged to explain the reasons of non-compliance. They have to present the Code consistency data of the company's operation and governance processes and procedures in their annual report. There is only one company listed on the Macedonian Stock Exchange super listing segment so far.

DE GRUYTER OPEN 
The aim of this paper is to examine the Macedonian companies' practices in a report of their environmental, social and sustainability activities. Thus, after this introductory aspect we review the scholars' concepts of non-financial reporting, the international organizations activities in promoting this reporting and the regulators and governments' practices to stimulate it in the next section. Next, we explain the methodology and the data we use in our research. Then, we move to the results of our survey of the practice of the Macedonian companies, presenting the reporting for social and environmental activities of selected Macedonian companies. Our research is based on their annual reports to the shareholders and on our survey of the personal views of their chief financial officers. After the presentation of our survey's results, in the last part of the paper, we present several conclusions and recommendations aimed to help the practitioners to better structure the reporting for these issues and to assist the key stakeholders of the related accounting legislative process in the Country. Our starting hypothesis is that there will be significant differences between the surveyed Macedonian companies and the prevailed practice worldwide. The results of this research will contribute to understanding the importance of the Macedonian companies environmental and corporate social responsibility reporting for greater transparency.

\section{Literature Review}

Traditional accounting concentrates on economic transactions and disregards social costs and the exploitation of natural resources. The most important task of accounting is to provide true and fair information for the stakeholder, which can be used to make a substantiated decision. However, if the system is built on deficient information, this goal cannot be achieved. Traditional accounting is a standardized system of statements that cannot quantify and take into account the limited quantity of natural resources (Gray et al., 1993), since it lacks relevant data (Jones, 2010). In recent time there is a much wider perception of accounting and its tasks in contemporary society puts the accounting in a position of provider of information not solely to the managers or investors, but to the society in general. In this sense Dillard et al. (2005) have stated that accounting should facilitate the sharing of information and should provide methods for the improvement of the operating processes' transparency. The increased awareness of the need for a new type of accounting to fulfill these new tasks can be traced back the mid 20th Century. It is now known as social accounting. The GRI Standards for Sustainability Reporting were introduced in the late 1990s and now are the most trusted and widely used in the world.

Chur et al. (2014) explained integrated-reporting as the convergence of the sustainability report and the financial report into a single "narrative" i.e. a communication intended mainly for investors in which top management provides its views on how sustainability issues and initiatives are expected to contribute to the long-term growth strategy of the business. According to Loew et al. (2004), the "new" accounting tries to incorporate ethics, social responsibility and ecological issues. Interest in these new topics further increased during the last quarter of the past Century, with scholars and practitioners reviewing the new role of accounting and the new

DE GRUYTER OPEN 
responsibility (mission) of the accounting to the society and the rationale and the value of publishing information about the social activities of the firms interest in environmental accounting was sparked particularly after some large-scale environmental industrial disasters of that time (Bhopal in 1984 and Exxon Valdez in 1989). Big multinational companies were threatening the environment all around the world. Since then society in general became much more sensitive to the issue, environmental accounting starting to attract much more attention, practically overshadowing the other aspects of the social accounting. Various researchers, such as Bebbington and Gray (2001), later Adams et al. (2004) or Brown et al. (2006) and many others emphasized the social and economic dimensions of sustainable development and the need for suitable reporting.

The awareness about the importance of environmental protection caused the research on environmental accounting to become much more attractive to scholars, for example Parker (2005), and Eugénio et al. (2010), leading to the recognition of environmental managerial and cost accounting. According to Schaltegger and Burritt (2000) environmental accounting includes the presentation and examination of the financial consequences of environmental protection as well as an analysis of the effects of the economic activity on certain environmental factors The main topics of scholarly research include the implications of environmental accounting and the ways of presentation of environmental issues in the annual reports. Although the environmental performance of a company is just one side of its social role, (maybe due to its easier quantification) according to Deegan (2002) and many others, much more interest was expressed in understanding, measuring and managing the environmental costs. The movement was so strong that some, like Jones referred to it as a process of "greening" of the accounting. Despite the bifurcation in their growth, environmental accounting may still be regarded as a sub-category of social accounting interested in the relationship between organization and its natural environment (Eugénio et al., 2010). Similarly, for and Burritt (2010) environmental accounting has an auxiliary function with a role to integrate the financial dimension of the impact of a company on its environment within the existing record-keeping systems.

Various models and frameworks for financial, social and environmental reporting have been offered on how to achieve it. Let's consider, for example, John Elkington who in his TripleBottom-Line Concept tried to integrate the financial, social and environmental dimensions of accounting (qtd. in Eugénio et al., 2010). Various standards and models for monitoring, reporting, and third party auditing of firm's environmental policy and responsibility emerged, like BS7750, then ISO14000 and EMAS in the area of environment. The Global Reporting Initiative was also established, and in the area of the social responsibility the Copenhagen Charter began to be utilized as a reference paper for equal concern to all stakeholders (Lamberton, 2005). However, Schaltegger and Burritt (2000) argued that all these concepts call for accounting based on physical units and thus could only be imbedded into the traditional managerial accounting, and only party (partly?) in the case of the financial reporting. For example, EMAS,

DE GRUYTER OPEN
Timisoara Journal of Economics and Business | ISSN: 2286-0991 | www.tjeb.ro Year 2015 | Volume 7 | Issue 2 | Pages: 220-231 
the EU-wide scheme implemented by the European Commission since 1993, tried to enable companies to simultaneously pursue environmental objectives and competitive targets in a synergetic way. However, while the empirical studies so far confirm a positive impact of a welldesigned environmental management system on environmental performance and technical and organizational innovativeness, they fail to prove the linkage with the other competitive variables such as market performance, resource productivity and intangible assets (the brand equity) of the organizations (Daddi et al. 2009).

As institutional investors are becoming increasingly aware of the reputational, operational, and regulatory benefits provided by effective sustainability management, CERES (2014) have issued a document as a proposal and set of investor recommendations on stock exchange listing standards, which are focused on corporate sustainability disclosure. The European Parliament recently approved, by the European Commission proposed Directive 2014/95, amending the Fourth and Seventh Accounting Directives on annual and consolidated accounts from 1978 and 1983 respectively, on the disclosure of non-financial and diversity information by certain large companies and groups in the EU. Inter alia, this new Directive involves mandatory disclosure in the management report about the developments, performance and position of the reporting entity on environmental, social and employee matters, respect for human rights, and anticorruption and anti-bribery measures. However, as with many of the other documents of the EU, on the side of the expectations there are many provisions that in fact could practically block its enforcement. For example, the Directive states that if a business in its non-financial statement fails to provide the required information, it should (only) provide clear and reasoned explanation for not doing so. Moreover, in the cases when such disclosure "would be seriously prejudicial to the commercial position of the undertaking, provided that such omission does not prevent a fair and balanced understanding of the undertaking's development, performance and position and of the impact of its activity", the member states are free to disobey to the requirements of the Directive 2014/95.

\section{Methodology}

We use qualitative analysis and comparative case studies of selected listed companies. The information and data were obtained primarily through desk research and study of relevant documentation. Prior to start the research we have discussed the issue of environmental reporting with CFO $\mathrm{s}$ from the companies in environmentally demanding sector. We have researched the literature and documents covering the law and the stock exchange listed regulation for environmental reporting.

In our survey, we examined the patterns of reporting for social and environmental activities of fifteen Macedonian companies which are in the first 80 of the list of 200 largest Macedonian companies by income (Kapital, 2015). The applied methodology has included a detailed desk study of their reporting practices from 2011 to 2014. We have examined their annual financial 
reports and their social and environmental responsibility reports when available. Finally, we were able to compare our results with those collected by the KPMG (2013) on the same issues, worldwide.

The sample was primarily made up of the ten companies that constitute the prime Macedonian Stock Exchange Index, MBI 10. There are 30 listed companies on the segments of super listing and stock exchange listing. One of the examined companies is listed in the super-listing segment, eight are in the listed segment, five are mandatory listed and one is non-listed on the Macedonian Stock Exchange. They belong to pharmaceutics, construction and building, distribution and sale of oil products, flat roll producing, banking, telecommunication, tourism, catering, and retail grocery trading sectors. We added five large companies in the oil industry, cement, metals, and confectionery and brewery sectors in order to get better mirroring of the industry sectors in Macedonia and in order to include companies with larger environmental footprints and consequently subjects to the highest environmental risk protection licensing. Six of examined companies (40\%) are foreign-owned and nine (60\%) are domestic. The survey includes information provided in both PDF and printed reports, as well as, in web-only content. We have used data from the companies' web pages and from the SEI-NET, the Macedonian stock exchange internet application for listed companies' reporting. We have accounted the reports published between 2012 and 2014. The findings are based on the analysis of available public information only.

\section{Results of the Survey}

According to ACCA (2015) businesses are 'citizens' of society in that they benefit from society and so owe duties back to society in the same way that individuals do. Many people no longer believe that businesses are able to take from society without also accounting back to society (and not just to shareholders), on how it has behaved with regard to its environmental impacts, they claim. The related reporting can occur in a range of media including the annual reports, 'stand-alone' reports, company websites, advertising or promotional media. Our research of the practice of the Macedonian companies shows that our companies use various names for this activity and the related reporting, from (38\%) using the term "Corporate Responsibility", "Environmental Protection" is used by 32\% and the terms "Corporate Social Responsibility" and "Social Responsibility" are used equally by $15 \%$ of the surveyed companies.

We have reviewed the availability of the information for company environmental activities in three categories: (i) on their web pages, (ii) in the annual reports, (iii) in the Management letters to the shareholders and (iv) whether they prepare CSR and Sustainability Reports and/or integrated reports. We evaluated the quality of reporting for the examined companies based on the amount of available information on their activities in environmental and social issues in four descriptive grades: (a) has detailed information, (b) has information, (c) has basic information and (d) has no information.

DE GRUYTER OPEN
Timisoara Journal of Economics and Business | ISSN: 2286-0991 | www.tjeb.ro Year 2015 | Volume 7 | Issue 2 | Pages: 220-231 
Mrsik, J. , \& Kostovski, N. (2015). of Economics and Business

Environmental and social responsibility reporting. Do Macedonian companies disclose those information and how?

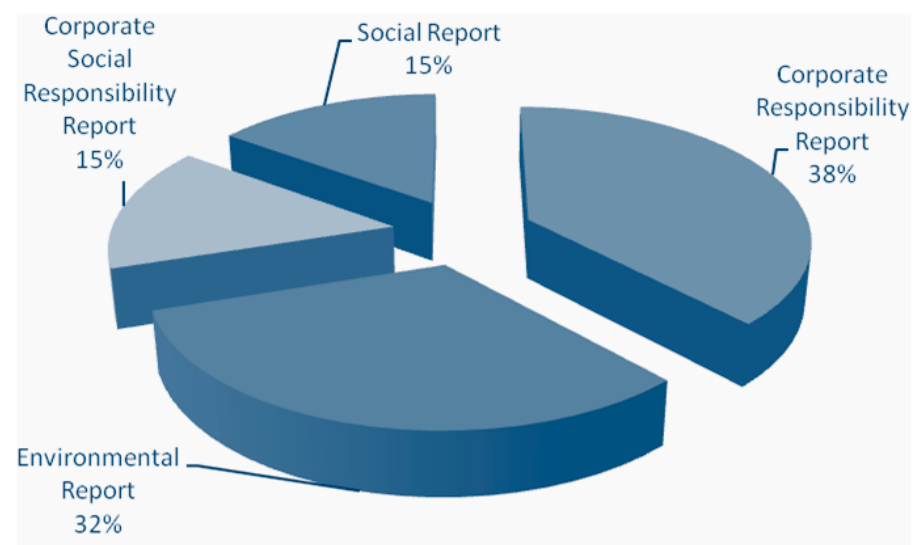

Figure 1. Pattern of referring to these reporting by surveyed Macedonian companies

After reviewing the related web sites, the results are as follows: one of the examined companies has detailed information for corporate social responsibility and environmental protection, three have basic information, eight have basic information only for corporate social responsibility and three have no information at all. One of the companies that have basic information on the web site in Macedonian language does not have the same information available on a translated web page in English.

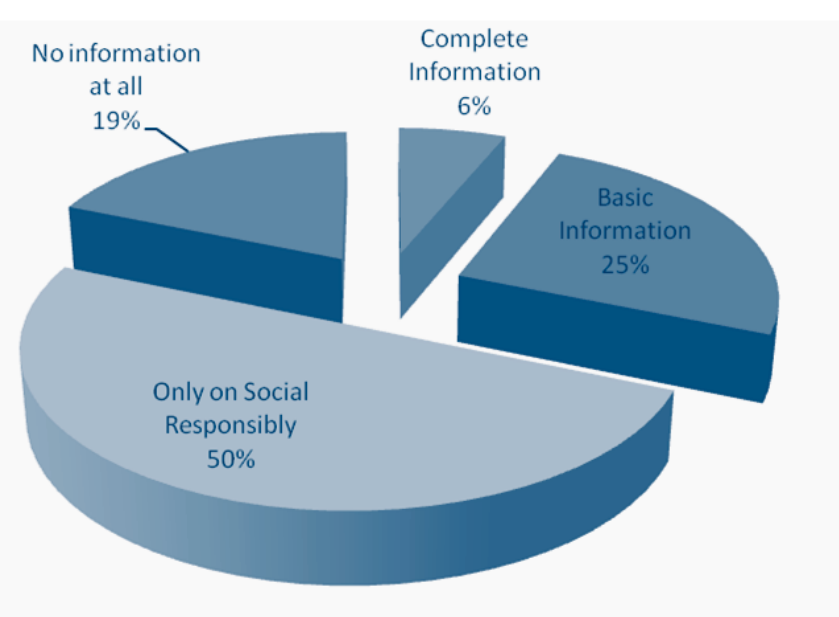

Figure 2. Availability of the Information on the web pages

In the second group of criteria, reporting on social responsibility in the annual reports to the stakeholders, only one company provides detailed report, four of the companies have some information on corporate social responsibility and 10 have no information at all. 


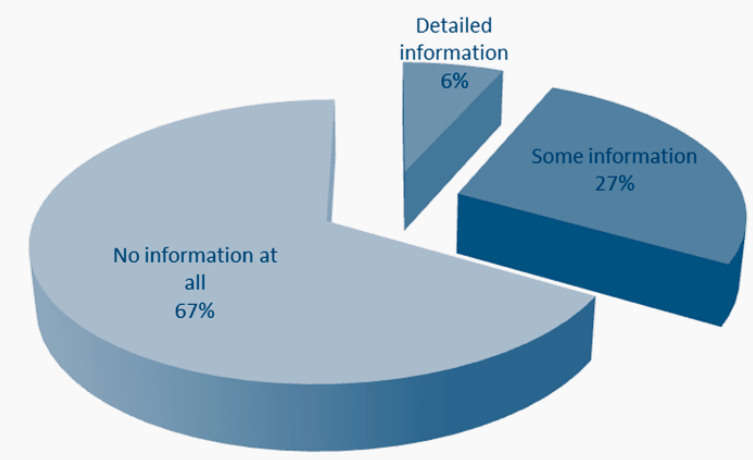

Figure 3. Availability of Information in annual reports of surveyed Macedonian companies

In relation to the assessment of the availability of the Information in the Letter to the Shareholders, in ten of the surveyed companies there is no reference in their letters to the shareholders in relation to any of the social and environmental issues, in three companies there is some information and only in two there is sufficient reference to these issues in their letters to the shareholders.

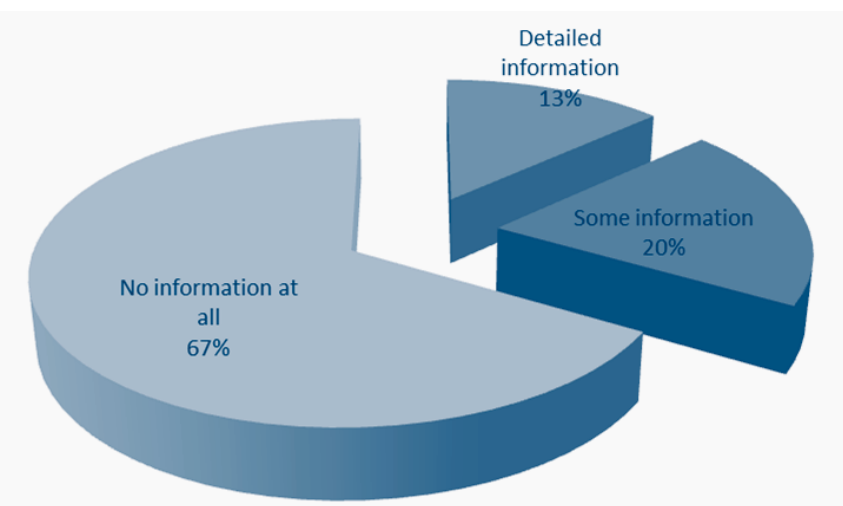

Figure 4. Availability of the social and environmental responsibility issues in letters to the shareholders

The ACCA (2015) report claims that most of the large companies produce a 'stand alone' reports concentrated on environmental and sometimes, on social issues, as well. In our research we have found only one Macedonian company that issues an annual Report on Corporate Social Responsibility and sustainable development. This company had been issuing this Report since 2009.

It is interesting to stress that the companies that otherwise have significant environmental impact are not referring to this issue in their annual reports to the stakeholders and to the public. Instead, they report on their social activities, job creation and charitable initiatives. Moreover, none of the companies identifies the business risks resulting from the social and environmental factors of their operations. The banks included in our survey do not include any assessments of the environmental and social impact and the related risks of their client businesses. 


\section{Conclusions and Recommendations}

In recent years, companies are increasingly considering how better to use financial, human and natural resources and to be accountable for the consequences of their decisions. Investors are becoming interested in analysis of the environmental performance of the listed companies when deciding where to invest. Consequently, there is a rising interest in the wider community of users of financial reports to introduce these issues into the annual reports and into the mandatory disclosures of investors' sensitive information. The companies themselves benefit from this revolutionary corporate reporting because it is helping them to emphasize the link between their own financial and non-financial performance. The market regulators and stock exchanges are playing an increasingly important role in encouraging good corporate governance and transparency of the listed companies.

However, despite the difficulties in presenting both the financial and non-financial information in a single report, a majority of the financial managers and investors agree on the benefits of the sustainability accounting and reporting. They think that integrated reporting helps create more elaborated decisions on the side of all interested parties, inside and outside of the companies. Consequently, they are trying to find the proper balance between the numbers in the standard financial reports and the environmental concerns in the narrative part of their annual reports or as independent environmental impact and social responsibility and good governance report, as practiced by many big companies.

Although non-financial or integrated reporting are not yet compulsory for companies in many countries, the stock markets' regulatory bodies and stock exchanges in developed countries are increasingly interested in requiring the non-financial disclosure requirements for the publicly traded companies. There are no obligatory requirements for companies in Macedonia to disclose their non-financial activities. Results of our survey of fifteen companies (fourteen of them listed on the Macedonian Stock Exchange and ten of them included into the MBI10 index) demonstrate low level of CSR reporting practice. The majority (93.3\%) of those companies do not publish social and environmental reports. Only one of the examined companies, who is owned by a multinational group, includes information on its social and environmental practices in the Annual Report that is available to the public via its website. It is far from the practice in other countries, where $56 \%$ is rate of inclusion of CSR data in annual reports in 2015 according to KPMG survey on 100 biggest companies in 34 countries worldwide (KPMG, 2015). Only one company prepares separate Social and Environmental Report, which is published on its web site, as well. Some of the companies even do not publish an Annual Report on their websites. The information that the examined companies have provided is very general and descriptive and they does not provide data about their environmental risk, costs and obligations. Because there is no obligation for the Macedonian companies to prepare environmental report they present only the positive aspects of their activities in order to improve the company's image.

DE GRUYTER OPEN
Timisoara Journal of Economics and Business | ISSN: 2286-0991 | www.tjeb.ro Year 2015 | Volume 7 | Issue 2 | Pages: 220-231 
Our starting hypothesis that there will be significant differences between the surveyed Macedonian companies and the prevailed practice worldwide, at least in the case of the Stock exchange: ten best performers and the selection of other five big Macedonian companies with significant environmental impact of their operations, was verified. According to the obtained results from the research, there is significant difference between the Macedonian companies CSR reporting practice and their counterparts worldwide. They do not give attention at all to the non-financial information in their annual reports by identifying business risks resulting from social and environmental factors.

Having in mind the internal and external benefits of the sustainability information for reporting companies it is recommendable to have an introduction of a sustainability reporting requirement for the companies in Macedonia. The low level of environmental and social responsibility reporting in the case of selected Macedonian companies is reflected by irrelevant and incomplete information provided by them, thus the environmental and social reporting is a challenge for the companies and the regulators. With our study we aim to encourage greater openness to information for social and environmental reporting practices among Macedonian companies as well as to initiate government policies towards promoting social and environmental reporting. Furthermore, since the government and the regulators have a direct interest in sustainability reporting they can employ an increasing amount of policies and regulations to promote the sustainability reporting of the companies. They can use additional measures to facilitate the process of reporting such as: creating guidelines and organizing trainings for environmental disclosure in annual reports, stimulating public debate for promoting a culture of transparency, motivating businesses to support specific initiatives and activities, supporting research and building practical capacity. The government can even promote a higher level of transparency in the environmental, social and governance spheres with its investment activities and with public-private partnerships.

Our intention is to continue this research by extending to a greater number and mostly those of 100 largest Macedonian companies which have strong influence on the environment. Our expectation is that we may find more than one best practices in environmental and social responsibility reporting among the Macedonian companies.

\section{References}

ACCA (2015). Environmental accounting and reporting. Retrieved from http://www.accaglobal.com/hk/en/student/exam-support-resources/professional-examsstudy-resources/p1/technical-articles/environmental-accounting-and-reporting.html.

Adams, C., Frost, G. and Webber, W. (2004) Triple Bottom Line: A review of the literature. In A. Heriques, and J. Richardson (eds.), The Triple Bottom Line: does it all add up (pp. 17-26). London: EarthScan.

Bebbington, J., \& Gray, R. (2001). An Account of Sustainability: Failure, Success and a Reconceptualisation. Critical Perspectives on Accounting, 12(5), 557-605.

DE GRUYTER OPEN 
Brown, D., Dillard, J., \& Marshall, R. S. (2006). Triple Bottom Line: A business metaphor for a social construct. Portland State University Working Paper. Retrieved from http://www.recercat.cat/ bitstream/handle/2072/2223/UABDT06-2.pdf?sequence=1.

Churet C., RobecoSAM, \& Eccles R. G. (2014). Integrated Reporting, Quality of Management, and Financial Performance. Journal of Applied Corporate Finance, 26(1).

CERES (2014). Investor listing standards proposal: Recommendations for Stock Exchange Requirements on Corporate Sustainability Reporting. Retrieved from http://www.ceres.org/resources/ reports/investor-listing-standards-proposal-recommendations-for-stock-exchangerequirements-on-corporate-sustainability-reporting.

Daddi, T, Iraldo, F., \& Testa, F. (2009). Environmental Certification for Organizations and Products: Management. Routledge \& Amazon.

Deegan, C. (2002). The legitimising effect of social and environmental disclosures - a theoretical foundation. Accounting, Auditing and Accountability Journal, 15(3), 282-311.

Dillard, J., Brown, D., \& Marshall, R. S. (2005). An environmentally enlightened accounting. Accounting Forum, 29, 77-101.

Eugénio, T., Lourenco, I. \& Morais, I. (2010). Recent developments in social and environmental accounting research. Social Responsibility Journal, 6(2), 286-305.

Gray, R., Bebbington, J. \& Walters, D. (1993). Accounting and the Environment (Greening of Accountancy II). London: Paul Chapman Publishing.

Hauser Institute for Civil Society. (2015). Corporate social responsibility disclosure efforts by national governments and stock exchanges. Retrieved from http://hausercenter.org/iri/wpcontent/uploads/2015/04/CSR-3-27-15.pdf.

Jones, M. J. (2010). Accounting for the environment: Towards a theoretical perspective for environmental accounting and reporting. Accounting Forum. 34, 123-138.

200 Largest Macedonian companies. Kapital 830. (2015, September 25). Kapital.

KPMG (2013). The KPMG survey of corporate responsibility reporting 2013. Retrieved from https://www.kpmg.com/Global/en/IssuesAndInsights/ArticlesPublications/corporate-

responsibility/Documents/corporate-responsibility-reporting-survey-2013-exec-summary.pdf.

KPMG (2015). Currents of change: The KPMG Survey on Corporate Responsibility Reporting 2015. Retrieved from http://www.kpmg.com/CN/en/IssuesAndInsights/ArticlesPublications/Documents/kpmgsurvey-of-corporate-responsibility-reporting-2015-0-201511.pdf.

Lamberton, G. (2005). Sustainability accounting - a brief history and conceptual framework. Accounting Forum. 29, 7-26.

Loew, T., Ankele, K., Braun, S., \& Clausen, J. (2004). Significance of the CSR debate for sustainability. Publications - Institute for Sustainability, Munster, Berlin

Macedonian Stock Exchange. (n.d.). Continuing obligation of the issuer. Retrieved from http://www.mse.mk/mk/content/24/1/2008/regular-obligations-for-reporting.

Parker, L. D. (2005). Social and environmental accountability research A view from the commentary boxs. Accounting, Auditing and Accountability Journal, 18(6), 842-860.

Schaltegger, S., \& Burritt, R. (2000) Contemporary Environmental Accounting, Issues, Concepts and Practice. Sheffield: Greenleaf.

Schaltegger, S. \& Burritt, R. L. (2010). Sustainability accounting for companies: Catchphrase or decision support for business leaders. Journal of World Business, 45, 375-384. 